\title{
The promotion of security sector reform strategies: Comparing the roles of the European Union and Canada
}

\author{
Antoine Vandemoortele ${ }^{1}$
}

\begin{abstract}
This article analyzes the role of the European Union (EU) and Canada in the promotion of Security Sector Reforms (SSR) activities in two regional organizations, the Organization for Security and Cooperation in Europe (OSCE) and the North Atlantic Treaty Organization (NATO). The concept of SSR seeks to address the effective governance of security in post-conflict environment by transforming the security institutions within a country in order for them to have more efficient, legitimate and democratic role in implementing security. Recent debates within the EU have led to the adoption of an SSR concept from the Council and a new strategy from the European Commission on the SSR activities. Within the framework of the ESDP, the EU has positioned itself as a leading actor, in this domain, including in its crisis management operations. On the other hand, Canada, through its whole-of government and human security programs has also been an important actor in the promotion of SSR activities. Yet, even though several international organizations (including the United Nations, the OSCE and NATO) are effectively doing SSR activities on the ground, there does not exist a common framework within any of these organizations despite the role of the EU and Canada. As such, it is surprising to found no global common policy for SSR while this approach is precisely holistic in its foundations. Taking these elements into consideration, this paper analyzes two specific aspects : a) the absence of a common policy framework within international organizations and b) the major differences between the approaches of the OSCE and NATO in the domain of SSR and the implications for the EU and Canada' roles.
\end{abstract}

Keywords: post-conflict reconstruction; security sector reform; multi-level governance; OSCE, NATO

\footnotetext{
${ }^{1}$ Antoine Vandemoortele is a PhD Researcher at the European University Institute. The author wishes to thank Frédéric Mérand, Stéphane Roussel and the participants at both YRN workshop in Montreal (March 2007) and Florence (April 2007). The author also wishes to acknowledge the administrative and financial support of the Research Group in International Security (REGIS),University of Montreal and McGill University.
} 


\section{Introduction}

After the demise of the Soviet Union and the end of the Cold War, one of the main challenges for the international community was to deal with a new security environment where regional conflicts and civil wars were multiplying around the globe. While on the theoretical level, this challenged the view of the 'end of history', it also had clear practical implications for the international community: how to develop tools, strategies and policies to cope with these new threats and to transform these zones of conflicts into zones of peace. These new practices of the international community towards these zones of conflicts include the development of new alliances, the transformation of peacekeeping into a more robust and strong proposal, the international administration of entire zones of conflicts, military invasion, sanctions and, in the case of the European Union and NATO, enlargement and membership prospects.

Addressing the issue of conflicts, wars and violence, however, is only one aspect of the entire security-development nexus (Stewart 2004). Transforming zones of conflict into zones of peace is the first step, but this needs to be reinforced by the transition from zones of peace toward zones of lasting and sustainable peace. This means that, in the domain of security, a double challenge emerged in the 1990s: conflict resolution and post-conflict reconstruction. This study aims to understand the latter and more specifically the development of new tools and strategies aimed at creating the conditions for a durable and peaceful security environment. The other objective of this study is to understand the evolution of the role of the international community in the practices of post-conflict reconstruction and to assess the different ways the international community dealt with this issue.

In order to do so, this paper focuses on the development, both on the field in post-conflict situations and at the international level, of security sector reforms strategies (SSR). While the Disarmament, Demobilisation and reintegration process (DDR) (Knight 2004) seeks the return of ex-combatants in the civil sphere following a conflict period, the process of Security Sector Reform (SSR) is a more comprehensive framework. The concept of SSR seeks to address the effective governance of security in post-conflict environment by transforming the security institutions within a country in order for them to have more efficient, legitimate and democratic role in implementing security. This includes the democratic control of the military complex, the redesign of civil-military relations and the professionalization of security services and the judiciary system (Clingendael 2002, Schnabel and Erhart 2005). In short, this approach seeks nothing less than the reinstitutionalization of the military, police, political and judiciary sectors to foster both internal (citizens) and external (state) security (Toft 2007). This concept was developed after the end of the Cold War as a possible way to be more efficient in addressing post-conflict reconstruction and the development of good governance. It has been experimented in Panama, El Salvador, Somalia, Haiti, East Timor and, on a larger scale, Kosovo and Afghanistan (Brzoska 2006).

However, while SSR has developed as a tool that helps in dealing with post-conflict reconstruction, a gap emerged between practices on the ground and debates at the international level, between the many international organizations and the donor community in general. In short, this means that will security sector reforms strategies have effectively been implemented in post-conflict situations, with mixed but often positive results (Law 2006a), the debate at the international level on how to 'do' SSR and how to develop a substantial reform agenda and have a positive impact has not been systematically addressed. First, even though (and at the same time, because of this) SSR strategies are meant to be holistic in nature, definitions within the donor community (European countries, Canada, United States of America, OECD, UN, NATO, OSCE) vary to large degree. Secondly, the approach towards SSR also varies, ranging from a security perspective to a more development-centred framework. Finally, the actors at the international community share different interests in doing SSR. 
For some, it is used as an instrument of power and influence, as a tool to enhance its own foreign policy structure, as an ideological aspect or simply (in a more pragmatic way) as another available policy in the toolbox to deal with post-conflict development and reconstruction (Law 2006).

In order to explain this puzzle, this gap between the local and international level, this paper focuses on two main actors in the development of security sector reforms practices and two regional security organizations. Thus, the main research problem is to analyze the promotion of security sector reforms at the international level using the case of two transatlantic security institutions, the North Atlantic Treaty Organization (NATO) and the Organization for Security and Cooperation in Europe (OSCE), and to understand these elements:

1) Why have these organizations failed to develop overarching framework in the field of security sector reform practices?

2) How can we explain the differences between the ways both organizations do SSR?

This study proposes that the main explanatory variable is the way member and participating states of these organizations have promoted the debate on SSR internally. More precisely, this study focuses on the role of two leading actors in the field, Canada and the European Union. By focusing on a set of actors and organizations that have a long history of interactions and where the same countries are often member and participating states of both organizations, this study follows a most-likely case scenario. This approach follows closely the one adopted by Checkel et al (2003) in their discussion of the socialization influence of international organizations. This means that if the findings of this study are not entirely conclusive, it would be difficult to apply this framework to other inter-institutional cases related to SSR (see also George and Bennett 2005).

\section{Hypothesis A}

The failure to develop an overall framework designed to spearhead security sector reforms practices in NATO and the OSCE is explained by the different mechanisms employed by the member and participating states (cooperation, competition AND-OR coordination) and the resulting division of labour where these members (mainly the European Union, Canada and the United States) attempt to take the lead on this issue.

\section{Hypothesis B}

The differences in the field of security sector reform policies between NATO and the OSCE can be explained by this same behaviour and the differences in the use of mechanisms of competition (in the case of NATO) or cooperation and norm-driven (in the case of the OSCE).

By highlighting the way actors behave and interact within these security institutions, this paper develops a multi-level governance framework that bridges over both rationalist (cost-benefits analysis) and sociological (understood at the micro-level analysis of individual actor interactions) perspective. This paper then presents the different mechanisms and explains the relative importance and the development of SSR practices using these mechanisms. The paper then shows that the differences in the practices of security sector reform for NATO and the OSCE are explained by the different pattern of behaviour (simply put, competitive or cooperative) of the main promoters of SSR (the EU, Canada and the United States).

By approaching this research puzzle on the evolution of security sector reforms at the local and international level using a narrower perspective (two actors and two organizations) enables us to gain a more precise and detailed understanding of a key aspect, namely the relationship and interactions 
between the principal actors involved, within the international community, in the promotion of SSR practices. This paper also attempts to contribute to the debates on the role of international organizations and the development of the EU as an international actor. On the theoretical level, this paper develops a multi-level governance approach that uses both institutionalist and constructivist input. On the empirical level, the objective is to understand the internal mechanisms of the debates and practices of security sector reforms and to highlight, in an exploratory way, the way these mechanisms are used and how they influence the outcomes of security sector reforms on the field. On the policy side, this project aims to provide some elements (best practices, lessons learned, positive interactions amongst actors) that may lead to policy recommendation as to better address and deal with the development of a common practice (or complementary practices) of security sector reforms.

The paper is divided as follows. The next section discusses the origins and evolution of security sector reform practices during the 1990s in order to frame the paper. This is done at three different levels: the field, where SSR has been experimented, the international and, more specifically, the development of SSR within the policies of Canada and the EU. The third section is used to present the theoretical and analytical framework, based on an institutionalist perspective, and to explain the main hypothesis and explanatory variables. The following two sections consist of the empirical focus of the paper and looks first at the different mechanisms that defined the debates on SSR practices at the international level and the role of Canada and the EU in these debates before moving towards an analysis of the impacts this has on both NATO and the OSCE. The final paper reviews these main findings and presents the way forward within this research agenda.

\section{The evolution of security sector reform practices}

Two dimensions of security sector reforms practices are taken into account in this section: the promotion at the international level and the implementation at the local and field levels.

\subsection{On the ground}

In order to understand the development of security sector reform in post-conflict environment, it us important to frame the initial debates on the development of strategies towards post-conflict reconstruction. In the early to mid 1990s, these debates have focused mainly on the transformation of the military and the changing dynamic of civil-military relations. This approach was also supplemented by DDR (disarmament, demobilization and reintegration programs). The security sector was, mostly, defined, as the external military dimension and aspects of political and judiciary institutions, democratization programmes were present, but not at the forefront. These elements of post-conflict reconstruction were, in short, increasing in terms of quantity and quality, but could not be described as a comprehensive and holistic view of security sector reform.

Following, the creation in the development donor community of the term security sector reform in 1998; several attempts have been made to tie together these individual aspects of security sector reform. This shift on the international level to a more general and broad security sector reform created the opportunity to integrate the different reform projects of the security sector into one roof. The impacts of the new debate on security sector reform were thus, in a large degree, reflected on the ground with mixed, but positive reviews (Brzoska 2006). In short, "while the concept itself was new in 1998, practically all of its components, such as reform of the defence forces, improvement in democratic oversight of armed forces, police reform, etc, were not" (Brzozka 2003) .

\subsection{The international level}


This however was not the case at the global or international level. "In surveying the global response to SSR, it is clear that there is a great deal underway that could fall under the rubric of SSR but is not in any way comprehensive" (Smith 2005). To understand this gap, it is important to understand the origins of this debate at the international level.

In Europe, the United Kingdom has been the main pioneer of security sector reforms as a way to link security and development issues together in post-conflict settings. In 1998, Clare Short, at that time UK Secretary of State for International Development, framed the concept of security sector reform, and its holistic approach, in public. While in Europe, the Netherlands and the UK remain the two main actors, the European Union has started to integrate the concept of SSR into its rhetoric and practices (albeit with some inconsistency on the implementation part, Sedra 2006) Following the European Security Strategy in December 2003, the Council of the European Union adopted an EU Concept for ESDP Support to Security Sector Reform in October 2005. This document highlights the aim of SSR activities under the ESDP, the internal division of labour expected between the Council and the Commission and the modalities and plan of action concerning the implementation of SSR. This was followed by a similar exercise by the Commission in its documents "A concept for European Community Support for Security Sector Reform” in May 2006. Finally, the Council adopted recently, in June 2006, a policy framework that is aimed at combining both approaches to SSR into an operational code of conduct. As such, in the framework of the European Union's external relations, the EU has positioned itself as the main actor involved in the promotion of the debate on security sector reform, most notably throughout its crisis management operations (rule of law mission in Iraq and Georgia, police mission in Bosnia-Herzegovina, Palestine, Macedonia and Condo and security sector reform assistance in RDC)

On the other hand, Canada has also been a core actor alongside the UK, Netherlands and the EU. Security sector reform debates were originally designed and promoted as new way of thinking the security-development nexus, reconceptualising notions of state security and recasting this approach in terms of human security. Since the mid-1990s, Canada has been a strong advocate of a human security agenda. This approach, developed largely with then Minister of Foreign Affairs Lloyd Axworthy, effectively seeks to address similar aspects than security sector reforms (individual security, democratic control of the military complex, new civil-military relations, good governance and lasting peace development) (Owens et Arneil 1999). More recently, in its International Policy Statement (2005), Canada has developed a plan of action at the international level that reflects this issue of security sector reform: the 3-D approach. This policy seeks to improve the existing practices of the role of Canada on the international scene and also in post-conflict setting by uniting the efforts of diplomacy, defence and development. Finally, with its strong engagement in Afghanistan, Canada has put into practice this notion of security sector reform in the context of Provincial Reconstruction Teams (Boivin 2006).

At the level of international organizations, some IOs, and especially regional organizations have started to deal with the notion of SSR, including NATO and the OSCE in Europe, ECOWAS or SAGD in Africa. The UN has, at the global level, engaged in discussions concerning the use of security sector reform. In February 2007, the Security Council held high-level discussions and an open debate on this issue, although the results have yet to be released (most probably a presidential statement is forthcoming). The UN is also active in coordinating SSR activities in Afghanistan (Toft 2006).

However, none of these organizations has developed an overall framework or a set of guidelines for the implementation of security sector reforms, despite the fact that in its conceptual origins, SSR precisely calls for a coordinated and holistic perspective. In fact, despite the rhetoric on SSR and the 
few but limited actions aimed at fostering better coordination, this lack of global framework is quite surprising. This is reinforced by the fact that the main actors involved in SSR are also members of these organizations (NATO, UN and OSCE and Canada, UK, EU and Netherlands).

This gap between rhetoric and practice is best explained by the absence of coordination amongst actors at the internal level (within national governments and between departments) and the external level (between different countries, institutions and organizations). The latter is what this project focuses on.

\section{External security governance and the making of security sector reform policies}

On the theoretical level, this project seeks to integrate elements of both institutionalism and constructivism. The main building blocks of this project are as follows. First, this project draws from the literature on multi-level governance (Hooghe and Marks 2004) attempting to understand the way that the debates on SSR within NATO and the OSCE are structured among these decision-making sites This can explain how institutionally the debate is developing. Yet it cannot account for what are the content and the process of these institutions related. The second aspect thus attempts to characterize the decision-making process within institutions using a security governance inspired framework (Krahmann 2003) In short, this multi-level governance approach to understanding the debates on security sector reform attempts to frame and highlight the mechanisms that support the interactions between these two institutions and the two actors under study, Canada and the European Union.

Finally, the third central element of this research design is to move the analysis from the domain of "high politics" to the sphere of "low politics". This means that the focus is on small level functional cooperation and not on the high-level rhetoric. The objective of this is to analyze the different mechanisms of the debate between a focus on high politics on which the main actors could not agree. By shifting the weight of the decision-making process to a much smaller scale, the main actors could provide a way forward. In short, this move from high politics to low politics is the central argument of this thesis and will be analyzed through the two elements mentioned above: a governance-inspired perspective on the dynamic of power relations and identity construction and an institutional perspective that builds on a multi-level governance view.

Three mechanisms can best explain the interactions amongst the donor community and, more precisely, the dynamic between EU, Canada, NATO and the OSCE. These mechanisms are used as explanatory variables: competition, coordination and division of labour.

The notion of inter institutional competition is the first mechanism described. It refers first to a non cooperation relation. This notion however can also be viewed as a strategic competition between different organizations over resources, policy choices, domains of actions and sphere of influence. Competition over resources reflects the fact that many international organizations share the same member countries and that they have to fight to gain the largest share of resources (financial, human, administrative, etc.) available. Different policy choices can also be the source of competition where the organizations attempt to gain control over a specific strategy. Taken together, these two elements are considered the internal competition, i.e. competition over the internal direction that these organizations adopt. On the other hand, competition over domains of actions (fight against terrorism, human security, defence reform, justice and legal reform for examples) and sphere of influence or territory of intervention (examples include NATO's Partnership for Peace programme, the EU's neighbourhood policy and the OSCE's claim of being the largest security organization, ranging from Vancouver to Vladivostok) are the external modes of competition between international 
organizations.

Another explanatory variable is the cooperation dimension. This is taken here in a very narrow sense. This mechanism refers to specific and limited scheme of cooperation between two organizations, for example the transfer of the mission in Bosnia and Herzegovina from the NATO-led SFOR to the EUled Althea operation in 2004 stands as a clear example.

Finally, this article proposes to revisit the notion of division of a labour and the so-called European security architecture debate that was prominent in the beginning of the 1990s. The notion of division of labour was a recurrent them in the early 1990s where several ideas where launched to integrate the different security organizations (NATO, EU, the OSCE). The idea of a hierarchical division of labour, usually with the OSCE as the organization with the broadest security agenda, has not however taken place. This is especially true due to the increasing role played by the EU and the development of the ESDP. However, while the conceptualization of an overall division of labour between these security organizations has failed to materialize, it is clear that some specific form of cooperation has been institutionalized. In this sense, the third mechanism seeks to present the way that these organizations cooperate not only on an ad hoc level, but also on broader terms. For example, until recently, the OSCE has remained the leader in security relations with the former Soviet Union Republics in Central Asia. Defence reform has also been the domain of NATO while the EU focused on civilian crisis management.

\section{Framing the debate within NATO and the OSCE: anarchy, hierarchy or division of labour?}

It is possible to understand this debate on the role of regional organizations by looking first at the different programmes implemented by both the OSCE and NATO. The objective of this section is to provide an overview of the roles and contributions of the OSCE and NATO in SSR policies on which it will be possible to compare and analyze the modes of interactions.

\subsection{NATO and Defence sector reform}

NATO activities in the field of security sector reform are centred on capacity-building and defence sector reform more precisely. Its sphere of activities lies both with the Euro-Atlantic developed countries and in post-conflict reconstruction. It is most active in the field of defence reform in the Balkans and Afghanistan and is also promoting security sector reform through the partnership for peace programme and its membership plan. This operational understanding of SSR, as opposed to a concept or framework, is seen in the lens of the Decalogue of norms for the PfP Defence Institution Building.

Regarding the Partnership for Peace Programme, NATO has developed the Individual Partnership Action Plans (IPAP) in which NATO and one PfP country agree to work together to achieve domestic reform impacts. The first country to sign an IPAP, Georgia in 2004, has since moved on to an intensified dialogue (ID) with NATO in 2006 which is the next step after the initial reform is set and may lead to a Membership Action Plan. The Georgia-NATO IPAP has led to a drafting of National security concept and the elaboration of a strategic defence review which sets the goal for the reform of the military and has paved the way for the transfer of the Minister of Defence to a civilian administration.

\subsection{The OSCE, norm-building and SSR}

The OSCE activities in the domain of SSR (Law 2006c) revolve around the norm-building dimension 
and are centred around the OSCE Code of Conduct on Politico-Military Aspects of Security (1994). This politically binding instrument while not effectively a SSR concept does provide a normative policy-oriented perspective for the development of SSR activities in the OSCE Long term missions (LTMs). The guiding lines of this code, linking security and stability to the democratic control of the security system (military, political and police-related complex) are reflected in the technicalassistance and norm-building approach to SSR from the OSCE. However, this code of conduct does not address all aspects of security sector reform and should be understood more as a normative tool rather than an overall framework.

The OSCE is particularly active in its long-term missions in the domains of police reform, border management and civil-military relations and the role of the civil society in the security sector. As such, the OSCE is not directly involved in defence reform per se; rather its comparative strength lies in its use of both development and security tools, geared in part by a human security agenda.

\subsection{Comparing and Contrasting NATO and the OSCE}

The different approaches used by NATO and the OSCE are quite different. For example, NATO relies on high level cooperation with individual countries and assists only indirectly in the local process of reform. The OSCE is however more present at the local level where its field missions have a large autonomy to conduct reforms and to help local ownership of the SSR process. In short, NATO has developed an operational understanding based on defence reform while the OSCE has used the Code of Conduct as a guideline for implementing norm-building SSR activities in its long term missions.

Once this overview done, one can argue that the mechanisms (competition, coordination and division of labour) have in fact an important influence on the absence of an overall framework guiding SSR activities and this can in turn explain the differences between NATO and the OSCE.

On the question of mechanisms, three elements are important to highlight. First, the competition mechanisms seem to be the main element that governs the relationship between NATO and the European Union. This is best explained by the absence of division of labour mechanisms and the intention of the EU of becoming an increasingly important international actor and the need to become the de facto crisis manager in the European security field. This is also explained by the general lack of coordination amongst the different actors, Canada, EU and both NATO and the OSCE. On the ground, this coordination is not very, as is highlighted for example in Afghanistan and the Provincial Reconstruction Teams. The third mechanism, division of labour, also seems to be a secondary factor. First, division of labour is not clearly defined between Canada, EU and NATO. This means that all actors attempt to 'do' SSR in the same geographic space, especially in Afghanistan and in the Balkans. However, there seems to be a better definition of roles between Canada, the EU and NATO where both Canada (with its human security program) and the EU leaving a substantial, but secondary role for the OSCE to play in the norm-building process of SSR activities. This means for example, that the OSCE is the primary actor in Central Asia.

This in turn better explains the differences between NATO and the OSCE. While NATO has developed an operational understanding and has put SSR rhetoric and elements in many important aspects of its program (PfP, membership plan, Afghanistan), it has had to deal with a lack of coordination and competition from other actors on the ground which has limited its capacity to develop an overall framework. By not being able to have a defined role on the ground and to implement specific (i.e. defence reform) aspects of SSR, NATO could not use a consistent set of SSR practices to shape a conceptual debate. The debates have also been limited at the international level 
because of this competition between the EU and NATO.

On the other hand, the OSCE has been able to find a niche in the field of SSR activities and has developed, using the Code of Conduct, limited, but substantial field activities. However, the division of labour between the OSCE, the EU and Canada has limited the capacity of the OSCE to go beyond this practical norm-building program and to update its Code of conduct to reflect conceptual development back from the field. This means that the EU and Canada wanted to keep the OSCE as a secondary actor by keeping it practical. This is also explained by the internal mechanisms of OSCE decision-making and the rule of consensus and actual crisis (Vandemoortele, 2006).

In short, one can argue that what best explains the differences between these organizations and the absence of an overall SSR framework is the interplay between the competition and cooperation (both ad hoc and institutionalized) mechanisms present in the EU-OSCE-NATO triangle. NATO has not adopted an overall framework in large part because it has to deal with the competition at the internal level (policy choices and resources) and the external level (especially the domain of action where NATO has created a niche for defence reform). It has also driven its SSR strategy on high level cooperation with individual countries because it has found a way to institutionalize its cooperation with the EU and the OSCE by targeting the element of defence reform within the SSR strategies.

The OSCE has to deal less with competition than the fact that its high-level of specialization (normbuilding and long term missions) has led to a division of labour where the OSCE's domain of intervention is shrinking while NATO and the EU are growing in the domain of SSR policies. The OSCE still remains an important SSR actor on the ground, but it is rapidly losing its distinctiveness and the internal competition over resources and policy choices has led to the failure of developing a new SSR strategy or at least an update of the 1994 Code of Conduct.

\section{Conclusion}

The preliminary results of this study highlights several key aspects surrounding the debates on security sector reform within the international community. The objective of this study was to understand why the OSCE and NATO have not developed overall SSR framework and what were the roles of the European Union and Canada in the promotion of these debates. By exploring the way that these institutions and actors have shaped the relationship and interactions using three mechanisms (competition, coordination and division of labour), this paper provided a better understanding of this debate.

On the policy side, this project also tried to put forward several elements of reflection and discussion that should be highlighted here and put together. First, the idea of understanding inter institutional dynamics in terms of competition and cooperation should put in perspective the debates on closer cooperation between the OSCE, NATO and the EU. This paper proposes to revisit the notions of competition and cooperation and proposes a roadmap to new forms of interaction in which specializations, sharing and pooling resources and a new non-hierarchical division of labour should be put to test. Secondly, this paper also puts forward the main positive elements of both the OSCE and NATO's attempts at security reform sector. Mainly, it is argued that NATO should continue its focus on defence reform while the OSCE should pursue its field operations. To improve NATO's defence reform activities, it would be important to share information with other organizations involved and to be more active in the process of local ownership of SSR policies. To improve the OSCE's long term missions, a better focus should be put on the objectives and key issues to be addressed in each mission depending on the context and the role played by SSR policies. The focus on local ownership of SSR policies should be maintained at all costs. 
The next logical step for this project will be to investigate, at the external level, why competition is the main lens through which the interactions between actors is conducted. At the internal level, a more detailed study of the decision-making processes in the EU and Canada would probably provide some elements to the way the promotion of SSR practices is done at the international level. Finally, a third important way forward would be to compare the impacts of SSR programs between these different actors and to look at the impacts for the local actors involved directly in post-conflict reconstruction. 


\section{Bibliography}

Boanas, Edward. 2005. "Crossing the fault line - coordinating multilateral security sector reform engagements in post-conflict countries". Journal of Security Sector Management 3:3 (June).

Boivin, Marc André. 2006. « The Afghan mission is in Canada's national interest». Inroads 20, p. 31-41.

Bonn International Center for Conversion .2004. Inventory of security sector reform efforts in developing and transition countries.

Brzoska, Michael. 2003. Development Donors and the Concept of Security Sector Reform. Geneva Centre for the Democratic Control of Armed Forces (DCAF), Occasional Paper No. 4.

Brzoska, Michael. 2006. "Introduction: Criteria for evaluating post-conflict reconstruction and security sector reform in peace support operations". International Peacekeeping, 13:1.

Chanaa, Jane. 2002. Security Sector Reform: Issues, Challenges and Prospects, Adelphi Papers, no. 344.

Checkel, Jeffrey, James A. Caporaso, and Joseph Jupille. 2003. Integrating Institutions: Rationalism, Constructivism and the Study of the European Union - Introduction. Comparative Political Studies 36 $(1-2)$.

Chuter, David. 2006. "Understanding Security Sector Reform". Journal of Security Sector Management 4:2 (April).

Clingendael (Netherlands Institute of International Relations). 2002. Towards a Better Practice Framework in Security Sector Reform: Broadening the Debate. Occasional SSR Paper No. 1 (Augusut).

Council of the European Union. EU Concept for ESDP support to Security Sector Reform (SSR), 12566/4/05 REV 4 (October 5, 2005)

Commission of the European Communities. A Concept for European Community Support for Security Sector Reform, COM(2006) 253 final (May 24, 2006)

Council of the European Union, Draft Council Conclusions on a Policy Framework for Security Sector Reform, 10168/06 (June 2, 2006)

Greene, Owen. 2003. "Security Sector Reform, Conflict Prevention and Regional Perspectives". Journal of Security Sector Management 1:1 (March).

Hall, Peter et Rosemary Taylor. 1996. «Political Science and the Three New Institutionalism» Political studies 44

Helly, Damien. 2006. «Security Sector Reform: From Concept to Practice», European Security Review 31 (December) 
Fitzgerald, Anne. 2003. 'Security Sector Reform -Streamlining National Military Forces to Respond to the Wider Security Needs', Journal of Security Sector Management 1:1.

Karkoszka, Andrezj. 2003. 'The Concept of Security Sector Reform' In Security Sector Reform: Its Relevance for Conflict Prevention,Peace Building, and Development. United Nations Office at Geneva and Geneva Centre for the Democratic Control of Armed Forces: Geneva.

Knight, Mark. 2004. «Guns, Camps and Cash: Disarmament, Demobilization and Reinsertion of Former Combatants in Transitions from War to Peace». Journal of Peace Research 41: 4, p.499-516.

Krahmann, Elke. 2005. "Security Governance and Networks: New Theoretical Perspectives in Transatlantic Security', Cambridge Review of International Affairs, vol.18, no.1, pp.19-34.

Krahmann, Elke. 2003. "Conceptualising Security Governance”, Cooperation and Conflict, Vol.38, No.1, pp.5-26.

Law, David. 2006. Intergovernmental Approaches to Security Sector Reform (SSR). Background paper for the workshop on "Developing a SSR Concept for the United Nations".

Law, David. 2006a. "Conclusion: Security sector (re)construction in post-conflict settings".

International Peacekeeping, 13:1.

Organization for economic cooperation and development (OECD). 2004. Security System Reform and Governance. Policy and Good Practice

Organization for economic cooperation and development (OECD). 2007. Handbook on SSR: Supporting Security and Justice.

Owens, Heather et Barbara Arneil. 1999. «The Human Security Paradigm Shift: A New Lens on Canadian Foreign Policy? Report of the University of British Columbia Symposium on Human Security». Canadian Foreign Policy 7:1.

Schnabel, Albrecht and Hans-Georg Ehrhart (dir.). 2005.Security Sector Reform and Post-Conflict Peac building. Tokyo: United Nations University Press.

Sedra, Mark. 2006. "European Approaches to Security Sector Reform: Examining Trends Through the Lens of Afghanistan". European Security, 15:3.

Short, Clare. 1998. 'Security, Development and Conflict Prevention', Speech at the Royal College of Defence Studies, London, 13 May 1998.

Smith, Chris. 2001. 'Security Sector Reform: Developmental Breakthrough or Institutional Reengineering.' Conflict, Security and Development 1:1.

Stewart, Frances. 2004. "Development and Security”. Conflict, security and development, 4 (3).

Sugden, Jennifer. 2006. "Security Sector Reform: the role of epistemic communities in the UK". Journal of Security Sector Management 4:4 (November). 
Tanner, Fred et Heiner Hanggi. 2005. Promoting security sector governance in the EU's neighbourhood. Chaillot Papers, European Union Security Studies Institute.

Toft, Monica. 2006. Peace through Security: Making Negotiated Settlements Stick. REGIS Working Paper 23 (November).

Vandemoortele, Antoine. 2006. Outsourcing its Future: The OSCE and the panel of Eminent Persons. Chroniques du GERSI 2 (1). 